\title{
Secondary Production of Monocorophium acherusicum (Amphipoda, Corophiidae) in a Seagrass Bed (Zostera marina)
}

\author{
Seung-Jin Jeong, Ok-Hwan Yu ${ }^{1}$ and Hae-Lip Suh* \\ Department of Oceanography, Chonnam National University, Gwangju 500-757, Korea \\ ${ }^{1}$ Marine Living Resources Research Division, Korea Ocean Research and \\ Development Institute, Ansan 425-600, Korea
}

\begin{abstract}
We measured the secondary production of the amphipod Monocorophium acherusicum Costa in a seagrass bed (Zostera marina L.) in Gwangyang Bay, southern Korea. M. acherusicum biomass was positively correlated $(\mathrm{P}<0.05)$ with seagrass standing crop, suggesting that there were biological interactions between the two species. $M$. acherusicum displays two main breeding periods per year: spring (March to April) and fall (October to November). M. acherusicum biomass in the spring breeding periods was higher than in the fall. Annual secondary production of $M$. acherusicum was $3.54 \mathrm{~g} \mathrm{DW} / \mathrm{m}^{2} / \mathrm{yr}$ with an annual $\mathrm{P} / \mathrm{B}$ ratio of 3.48 . Secondary production and the $\mathrm{P} / \mathrm{B}$ ratio of $M$. acherusicum were lower than those observed for other amphipods inhabiting seagrass beds. These results suggest that biological interactions between $M$. acherusicum and seagrass, as well as dietary competition with other amphipods can potentially cause declines in secondary production and the $\mathrm{P} / \mathrm{B}$ ratio.
\end{abstract}

Key words: Monocorophium acherusicum, secondary production, seagrass beds, Zostera marina

\section{Introduction}

Gammarid amphipods are considered one of the most important secondary producers in seagrass beds (Fredette and Diaz, 1990). Amphipods utilize primary food sources, such as detritus and phytoplankton, and also serve as prey for higher level consumers, such as fish and large crustaceans (Nelson, 1979; Vetter, 1995; Derrick and Kennedy, 1997). Gammarid amphipods display rapid turnover rates (Drake and Arias, 1995), and can become dominant within seagrass beds (Jeong et al., 2004).

The corophiid Monocorophium acherusicum occurs along the west and south coasts of Korea, in Japanese coastal waters, and from Alaska to California along the Pacific coast of North America (Carlton, 1979; Ishimaru, 1994). M. acherusicum is the most widely distributed species of corophiid amphipod in the world's temperate-tropical waters (Bousfield and Hoover, 1997). A few studies have briefly addressed the distribution and systematics of $M$. acherusicum (Stebbing, 1899; Barnard and Karaman, 1991), whereas many studies have inves-

\footnotetext{
*Corresponding author: suhhl@chonnam.ac.kr
}

tigated amphipod secondary production (Jeong et al., 2006). However, most of these latter studies focused on amphipod species in unvegetated habitats (Jeong et al., 2006), and consequently, amphipod secondary production in seagrass beds remains largely unstudied Moreover, no attempts have been made to measure the secondary production of $M$. acherusicum.

The objectives of the present study were to measure annual variation in $M$. acherusicum biomass and to estimate this species' secondary production in seagrass beds in southern Korea.

\section{Sampling}

\section{Materials and Methods}

The sampling site was a sublittoral seagrass bed (Zostera marina) surrounded by rock in the northwest part of Namhae-do $\left(34^{\circ} 48^{\prime} \mathrm{N}, 127^{\circ} 49^{\prime} \mathrm{E}\right)$, Gwangyang Bay, Korea (Jeong et al., 2006). Tidal levels were measured as the distance $(\mathrm{cm})$ above and below mean sea level (MSL) at Gwangyang (NORI, 2002). The annual tidal range varied from $415 \mathrm{~cm}$ above to 22 $\mathrm{cm}$ below MSL. Seagrass beds were distributed along the shoreline and were $10-30 \mathrm{~m}$ wide and 90-100 m 
long. Water temperature and salinity ranged from 9.2$26.4^{\circ} \mathrm{C}$ and from 10.9-31.6 psu, respectively. During the rainy season, the lowest salinities occurred in August and were caused by runoff from the Seomjin River near the sampling site.

Sampling was carried out monthly from January to December 2002 at the spring tide low water mark. Three replicate samples were collected using a diveroperated hand-held net $(15 \times 15 \mathrm{~cm}$ mouth, $0.15 \mathrm{~mm}$ mesh). The net was carefully placed over the seagrass, covering the tips of leaves to the rhizome, and the mouth of the net was closed before cutting the rhizomes. To avoid disturbance of the sediments, we sampled the upper $-15 \mathrm{~cm}$ of the bottom. The seagrass samples were transported to the laboratory, where animals were separated from the seagrass by rinsing with filtered sea water.

Seagrass dry weight was measured after drying for $24 \mathrm{hr}$ at $60^{\circ} \mathrm{C}$ and weighed to the nearest $0.01 \mathrm{~g}$ using an electronic microbalance (Model UMT2, Mettler Instrument, Columbus, Ohio, USA). Animals separated from the seagrass were immediately preserved in $5 \%$ borate-buffered formaldehyde with filtered sea water. Individuals of Monocorophium acherusicum were sorted and counted under a dissecting microscope. The size of individuals was determined by measuring the length of the animal from the tip of the rostrum to the end of the telson under a dissecting microscope fitted with an image analysis system (Image Pro Plus 2.0, Media Cybernetics, Silver Springs, Maryland, USA).

\section{Biomass}

Additional biomass samples were collected from March to May 2004. After collection, live individuals of $M$. acherusicum were sorted under a dissecting microscope and placed separately into vials filled with filtered sea water. Animals were then transported to the laboratory and were allowed to clear their guts. Subsequently, all live $M$. acherusicum were incubated for $48 \mathrm{hr}$ without food. After incubation, live animals were rinsed with distilled water and the body length (BL, in $\mathrm{mm}$ ) was measured. For dry weight measurements, specimens were dried for $24 \mathrm{hr}$ at $65^{\circ} \mathrm{C}$ and then individually weighed to the nearest $0.1 \mu \mathrm{g}$ using an electronic microbalance. Relationships between dry weight (DW, in $\mathrm{mg}$ ) and $\mathrm{BL}$ were estimated using the exponential equation: $\mathrm{DW}=\mathrm{aBL}^{\mathrm{b}}$.

\section{Secondary production}

Amphipods cohorts within seagrass beds were difficult to separate; thus, Monocorophium acherusicum secondary production was estimated using the size-frequency method (Hynes, 1961). This method is based on the use of the average size-frequency distribution to sum the total losses between size classes, based on monthly samples taken throughout the year (Hamilton, 1969). We used Benke's (1979) modification of the basic production equation of the Hynes method (Hynes, 1961; Hamilton, 1969):

$$
P=\left(I \sum_{j=1}^{i}\left(\bar{N}_{j}-\bar{N}_{j+1}\right) \times \sqrt{\bar{W}_{j} \bar{W}_{j+1}}\right) \times(365 / \mathrm{CPI})
$$

where $P$ is annual production, $I$ is the number of times loss factor, $i$ is the number of size classes, $N_{j}$ is the mean number of individuals in size class $j$ (averaged over the entire year), $W_{j}$ is the mean DW of individuals in size class $j$, and CPI is the cohort production interval (in days) from hatching to attaining the largest size class. When there were differences in the maximum length of males and females, we selected the lower times loss factor to avoid overestimating production (Waters and Hokenstrom, 1980). Annual production was the sum of production in each size class multiplied by $365 / \mathrm{CPI}$ to account for multiple broods (Benke, 1979). The life cycle of corophiid amphipods ranges from 8-11.5 months (Moore, 1981). The life cycle of M. acherusicum was nearly 1 year (Jeong, unpublished data), therefore the value of 365/CPI was not modified. The accuracy of the size-frequency method increases with the use of smaller size intervals (Cushman et al., 1978). The mean size of newly hatched juveniles of $M$. acherusicum was $0.8 \mathrm{~mm}$ (Fig. 2); therefore, we used $1 \mathrm{~mm}$ size class intervals to estimate secondary production.

\section{Results and Discussion}

\section{Biomass}

Seagrass standing crop exhibited two peaks throughout the year (Fig. 1). The first peak occurred when the standing crop increased from $60 \mathrm{~g} \mathrm{DW} / \mathrm{m}^{2}$ in February to $838.51 \mathrm{~g} \mathrm{DW} / \mathrm{m}^{2}$ in May, which was followed by a decrease to $240.43 \mathrm{~g} \mathrm{DW} / \mathrm{m}^{2}$ in August (Fig. 1). After September, the standing crop increased again to reach a second peak at $338.60 \mathrm{~g} \mathrm{DW} / \mathrm{m}^{2}$ in November (Fig.1). The biomass distribution of Monocorophium acherusicum was similar to patterns in seagrass standing crop (Fig. 2). M. acherusicum biomass and seagrass standing crop were signifycantly positively correlated (Pearson's correlation test $\left.\mathrm{n}=181, \mathrm{r}^{2}=0.67, \mathrm{P}<0.05\right)$. M. acherusicum is an herbivorous feeder. The main food of $M$. acherusicum consists of seagrass tissues and benthic diatoms (Jeong, unpublished data). Seagrass standing crop 


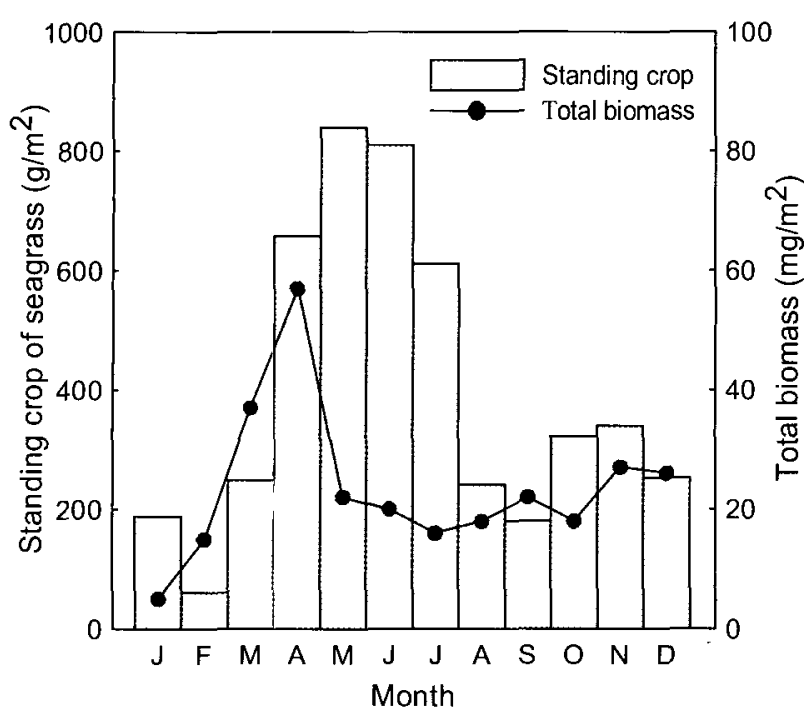

Fig. 1. Seasonal variation in total biomass (DW) of Monocorophium acherusicum and standing crop (DW) of seagrass.



Fig. 2. Seasonal variation in biomass (DW) of Monocorophium acherusicum.

was tightly correlated with the food items of $M$. acherusicum, as was previously observed by Fredette and Diaz (1990) for Gammarus mucronatus.
The significant relationship between $\mathrm{BL}$ and $\mathrm{DW}$ of $M$. acherusicum is presented by the regression equation:

$$
\mathrm{DW}=0.025 \mathrm{BL}^{2.16}\left(\mathrm{n}=159, \mathrm{r}^{2}=0.90, \mathrm{P}<0.05\right) .
$$

M. acherusicum Breeding periods were also closely related to seagrass growth periods. The biomass of each size class was lower in the fall than in other seasons, but the proportion of small individuals was higher in the fall (Fig. 2). The biomass of small individuals $(<3 \mathrm{~mm})$ was greater than that of large individuals $(>3 \mathrm{~mm})$ in the spring and fall, whereas the biomass of large individuals increased during the summer and winter before the breeding period. The maximum lengths of males and females were 8.25 $\mathrm{mm}$ and $8.75 \mathrm{~mm}$, respectively. The annual biomass of $M$. acherusicum was $1.02 \mathrm{~g} \mathrm{DW} / \mathrm{m}^{2} / \mathrm{yr}$.

Mean dry weights of $M$. acherusicum were low during the spring, and then rapidly increased during the summer (Fig.3). The maximum mean dry weight was $0.92 \mathrm{mg}$ in August (Fig. 3). During the spring and fall breeding periods, densities were high, even though mean dry weight was lower than in other periods (Fig. 3). Jeong et al. (2006) reported that the density of Jassa slatteryi rapidly increased from April to May, followed by high densities in June and July. In contrast, the density of $M$. acherusicum increased from February to April and then rapidly decreased in May (Fig. 3). J. slatteryi feed primarily on benthic diatoms, algal tissues, and detritus (Jeong et al.,

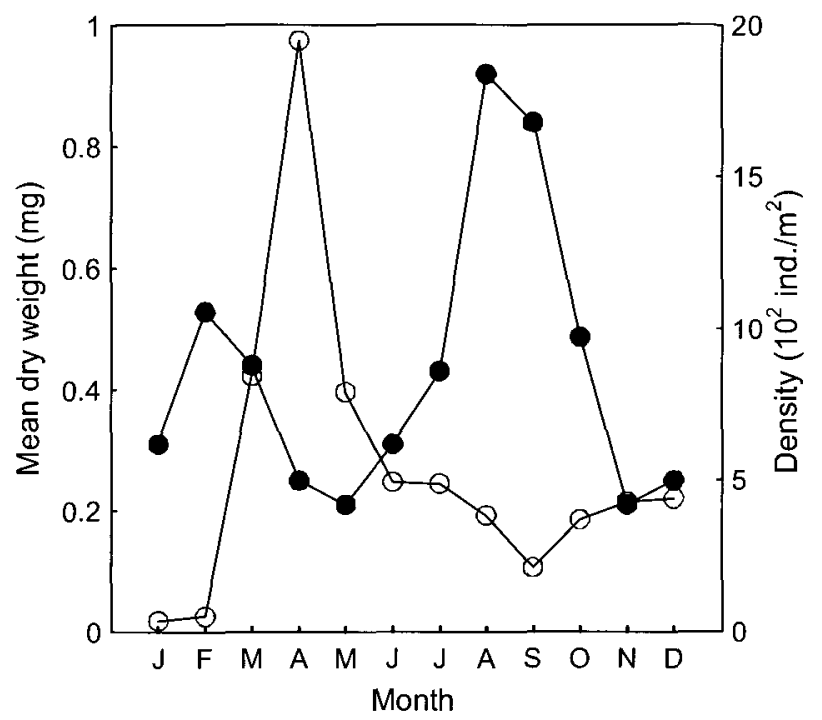

Fig. 3. Seasonal variation in mean dry weight (solid circles) and density (open circles) of Monocorophium acherusicum. 
Table 1. Estimation of secondary production of Monocorophium acherusicum on the seagrass beds of Gwangyang Bay by the size-frequency method. Biomass expressed as dry weights

\begin{tabular}{ccccccccc}
\hline $\begin{array}{c}\text { Size } \\
\text { group } \\
(\mathrm{mm})\end{array}$ & $\begin{array}{c}\text { Density } \\
\left(\text { ind } / \mathrm{m}^{2}\right)\end{array}$ & $\begin{array}{c}\text { Mean wt. } \\
(\mathrm{mg})\end{array}$ & $\begin{array}{c}\text { Standing stock } \\
\left(\mathrm{g} / \mathrm{m}^{2}\right)\end{array}$ & $\begin{array}{c}\text { Individuals lost } \\
\left(\text { ind. } / \mathrm{m}^{2}\right)\end{array}$ & $\begin{array}{c}\text { Wt. at loss } \\
(\mathrm{mg})\end{array}$ & $\begin{array}{c}\text { Weight loss } \\
\left(\mathrm{g} / \mathrm{m}^{2}\right)\end{array}$ & $\begin{array}{c}\text { Number of } \\
\text { time loss }\end{array}$ & $\begin{array}{c}\text { Production } \\
\left(\mathrm{g} / \mathrm{m}^{2}\right)\end{array}$ \\
\hline $0-1$ & 0.25 & 0.00 & 0.00 & -35.31 & 0.02 & 0.00 & 9.00 & -0.01 \\
$1-2$ & 35.56 & 0.09 & 0.00 & -62.22 & 0.14 & -0.01 & 9.00 & -0.08 \\
$2-3$ & 97.78 & 0.23 & 0.02 & -284.45 & 0.30 & -0.09 & 9.00 & -0.77 \\
$3-4$ & 382.23 & 0.40 & 0.15 & -80.00 & 0.50 & -0.04 & 9.00 & -0.36 \\
$4-5$ & 462.23 & 0.63 & 0.29 & 235.56 & 0.83 & 0.20 & 9.00 & 1.77 \\
$5-6$ & 226.67 & 1.10 & 0.25 & 84.44 & 1.32 & 0.11 & 9.00 & 1.00 \\
$6-7$ & 142.23 & 1.59 & 0.23 & 115.56 & 1.68 & 0.19 & 9.00 & 1.74 \\
$7-8$ & 26.67 & 1.77 & 0.05 & 14.22 & 1.85 & 0.03 & 9.00 & 0.24 \\
$8-9$ & 12.45 & 1.93 & 0.02 & 12.45 & 0.00 & 0.00 & 9.00 & 0.00 \\
\hline
\end{tabular}

Table 2. Secondary production, $\mathrm{P}\left(\mathrm{g} \mathrm{DW} / \mathrm{m}^{2} / \mathrm{yr}\right)$ and annual $\mathrm{P} / \mathrm{B}$ ratio for amphipods inhabiting seagrass beds

\begin{tabular}{lllclll}
\hline Species & Location and depth $(\mathrm{m})$ & Habitat & $\mathrm{P}$ & $\mathrm{P} / \mathrm{B}$ & Source \\
\hline Gammans mucronatus Say, 1818 & Chesapeake Bay (0.3-1.0), U.S.A. & Seagrass beds & 14.3 & $23.6-76.8$ & Fredette and Diaz, 1990 \\
Gammanis mucronatus Say, 1818 & York River, U.S.A. & Seagrass beds & $5-10$ & $15.8-36.8$ & Fredette and Diaz, 1986 \\
Jassa slatteryi Conlan, 1990 & Gwangyang Bay (1-1.5), Korea & Seagrass beds & 20.07 & 5.21 & Jeong et al., 2006 \\
Monocorophium achenisicum Costa, 1851 & Gwangyang Bay (1-1.5), Korea & Seagrass beds & 3.54 & 3.48 & The present stuty \\
\hline
\end{tabular}

2004). Thus, the diets of $M$. acherusicum and $J$. slatteryi may overlap considerably. This large overlap in dietary composition increases interspecific competition for food (Yu et al., 2003), which can cause declines in amphipod population density and biomass (Sarvala, 1986; Hill, 1992). Therefore, we suggest that competition for food between $M$. acherusicum and $J$. slatteryi may have led to low densities of $M$. acherusicum from May to July.

\section{Production}

Marine amphipods have a wide range of secondary production according to species and habitat type (Jeong et al., 2006). Amphipod production in unvegetated habitats ranged from $0.1-47 \mathrm{~g} \mathrm{DW} / \mathrm{m}^{2} / \mathrm{yr}$ (Jeong et al., 2006). In contrast, the highest production in seagrass beds $\left(20.07 \mathrm{~g} \mathrm{DW} / \mathrm{m}^{2} / \mathrm{yr}\right)$ was reported for Jassa slatteryi in Gwangyang Bay, Korea (Table 2). Monocorophium acherusicum secondary production was $3.54 \mathrm{~g} \mathrm{DW} / \mathrm{m}^{2} / \mathrm{yr}$ (Table 1), which was lowest among the observed production of seagrass-dwelling amphipods (Table 2). Secondary production of marine benthic amphipods in seagrass beds often increases with increasing amphipod density (Fredette and Diaz, 1986). Consequently, the low secondary production in $M$. acherusicum may be related to the observed low densities of this species (compared to other amphipods).

$\mathrm{P} / \mathrm{B}$ ratios of benthic amphipods are generally higher in vegetated than unvegetated habitats (Orth et al., 1984). P/B ratios of amphipods living in seagrass beds ranged from 5.21 to 76.8 (Table 2). The annual P/B ratio of Monocorophium acherusicum was 3.48, which was low compared to other seagrass amphipods (Table 2). Dauvin (1989) reported that the $\mathrm{P} / \mathrm{B}$ ratio appears to be closely related to the number of amphipod generations. A high number of generations and subsequent high $\mathrm{P} / \mathrm{B}$ ratios are characteristic of short-lived, multivoltine species (Kemp et al., 1985; Donn and Croker, 1986). M. acherusicum has fewer generations than other amphipods, perhaps leading to the lower $\mathrm{P} / \mathrm{B}$ ratios.

In comparison to other habitats, seagrass beds provide a superior substrate for diverse and abundant invertebrate communities (Orth et al., 1984). In seagrass beds, benthic amphipods are an important food resource for fishes and crustaceans. Recently, in a year-round survey in Gwangyang Bay, the secondary production of Jassa slatteryi was estimated as $20.07 \mathrm{~g}$ $\mathrm{DW} / \mathrm{m}^{2} / \mathrm{yr}$, which was the highest production observed for seagrass-dwelling amphipods (Jeong et al., 2006). In addition, Gammaropsis japonicus exhibited the highest abundance during the year (Jeong et al., 2004). High abundance and secondary production of amphipods may play important roles in the energy flow between primary production and higher consumers in the seagrass beds of southern Korea. Therefore, to better understand the role of amphipods in seagrass bed ecosystems, we need more detailed information on these species' life cycles and secondary production. 


\section{Acknowledgements}

We are grateful to H.G. Jeong, S.G. Seon, and J.I. Park for assistance in the field and with data processing. We also thank three anonymous reviewers for helpful suggestions. This study was financially supported by a research fund of Chonnam National University in 2004.

\section{References}

Barnard, J.L. and G.S. Karaman. 1991. The families and genera of marine of gammaridean Amphipoda (except marine gammaroids). Rec. Austral. Mus., Suppl., 13, 1- 866.

Benke, A.C. 1979. A modification of the Hynes method for estimating secondary production with particular signifycance for multivoltine populations. Limnol. Oceanogr., 24, 168-171.

Bousfield, E.L. and P.M. Hoover. 1997. The amphipod superfamily Corophioidea on Pacific coast of North America. Part V. Family Corophiidae: Corophiinae, new subfamily. Systematics and distributional ecology. Amphipacifica, 2, 1-119.

Carlton, J.T. 1979. History, biogeography and ecology of the introduced marine and estuarine invertebrates of the Pacific coast of North America. Ph.D. Thesis, The Univ. of California, Davis, 1-904.

Cushman, R.M., H.H. Shugart, S.G. Hildegrand and J.W. Elwood. 1978. The effect of growth curve and sampling regime on instantaneous-growth, removalsummation, and Hynes/Hamilton estimates of aquatic insect production: a computer simulation. Limnol. Oceanogr., 23, 184-189.

Dauvin, J.C. 1989. Life cycle, dynamics and productivity of Crustacea-Amphipoda from the western English Channel. 5. Ampelisca sarsi Chevreux. J. Exp. Mar. Biol. Ecol., 128, 31-56.

Derrick, P.A. and V.S. Kennedy. 1997. Prey selection by the hogchoker, Trinectes maculatus (Pisces: Soleidae), along summer salinity gradients in Chesapeake Bay, USA. Mar. Biol., 129, 699-711.

Donn, T.E., Jr. and R.A. Croker. 1986. Seasonal patterns of production in the sandy-beach amphipod Haustorius canadensis. Estuar. Coast. Shelf Sci., 22, 675-687.

Drake, P. and A.M. Arias. 1995. Distribution and production of Microdeutopus gryllotalpa (Amphipoda: Aoridae) in a shallow coastal lagoon in the Bay of Cadiz, Spain. J. Crust. Biol., 15, 454-465.

Fredette, T.J. and R.J. Diaz. 1986. Secondary production of Gammarus mucronatus Say (Amphipoda: Gammaridae) in warm temperate estuarine habitats, York River, Virginia. J. Crust. Biol., 6, 729-741.

Fredette, T.J. and R.J. Diaz. 1990. Secondary production within a seagrass bed (Zostera marina and Ruppia marina) in lower Chesapeake Bay. Estuaries, 13, 431440.

Hamilton, A.L. 1969. On estimating annual production. Limnol. Oceanogr., 14, 771-782.

Hill, C. 1992. Interactions between year classes in the benthic amphipod Monoporeia affinis: effects on juvenile survival and growth. Oceologia, 91, 157-162.

Hynes, H.B. 1961. The invertebrate fauna of a Welsh mountain stream. Arch. Hydrobiol., 57, 344-388.

Ishimaru, S. 1994. A catalogue of gammaridean and ingolfiellidean Amphipoda recorded from the vicinity of Japan. Rep. Sado Mar. Biol. Sta., Niigata Univ., 24, $1-86$.

Jeong, S.J., O.H. Yu and H.L. Suh. 2004. Seasonal variation and feeding habits of amphipods inhabiting Zostera marina beds in Gwangyang Bay, Korea. J. Kor. Fish. Soc., 37, 122-128.

Jeong, S.J., O.H. Yu and H.L. Suh. 2006. Secondary production of Jassa slatteryi (Amphipoda, Ischyroceridae) on a seagrass bed (Zostera marina L.) in southern Korea. Mar. Ecol. Prog. Ser., 309, 205-211

Kemp, P.F., F.A. Cole and R.C. Swartz. 1985. Life history and productivity of the phoxocephalid amphipod Rhepoxynius abronius (Barnard). J. Crust. Biol., 5, 449-464.

Moore, P.G. 1981. The life histories of the amphipods Lembos websteri Bate and Corophium bonnellii Milne Edwards in kelp holdfasts. J. Exp. Mar. Biol. Ecol., 49, $1-50$.

Nelson, W.G. 1979. Experimental studies of selective predation on amphipods: consequences for amphipod distribution and abundance. J. Exp. Mar. Biol. Ecol., $38,225-245$.

NORI (National Oceanographic Research Institute, Korea). 2002. Tide Tables. Vol. 510, Inchon, Korea, 1-37.

Orth, R.J., K.L. Heck, Jr. and J. Van Montfrans. 1984. Faunal communities in seagrass beds: a review of the influence of plants structure and prey characteristic on predator-prey relationship. Estuaries, 7, 339-350.

Sarvala, J. 1986. Interannual variation of growth and recruitment in Pontoporeia affinis (Lindström) (Crustacea: Amphipoda) in relation to abundance fluctuations. J. Exp. Mar. Biol. Ecol., 101, 41-59.

Stebbing, T.R.R. 1899. Revision of Amphipoda. Ann. Mag Nat. Hist., 7, 1-350.

Vetter, E.W. 1995. Detritus-based patches of high secondary production in the nearshore benthos. Mar. Ecol. Prog. Ser., 120, 251-262.

Waters, T.F. and J.C. Hokenstrom. 1980. Annual production and drift of the stream amphipod Gammarus pseudolimnaeus in Valley Creek, Minnesota. Limnol. Oceanogr., 25, 700-710. 
Yu, O.H. and H.L. Suh. 2002. Secondary production of Synchelidium lenorostralum (Amphipoda, Oedicerotidae) on a temperate sandy shore, southern Korea. J. Crust. Biol., 22, 467-473.

Yu, O.H., H.L. Suh and Y. Shirayama. 2003. Feeding ecology of three amphipod species Synchelidium lenorostralum, S. trioostegitum and Gitanopsis japonica in the surf zone of a sandy shore. Mar. Ecol. Prog. Ser., 258, 189-199.

(Received September 2005, Accepted May 2006) 